\title{
A Narrative Inquiry Into Pre-Service English Teachers' Temporal Investments in Their Initial Education Curriculum
}

\section{Una indagación narrativa en las inversiones temporales de estudiantes de grado del profesorado de inglés en su currículo de formación inicial*}

\author{
María Cristina Sarasa \\ mcsarasa@hotmail.com \\ Universidad Nacional de Mar del Plata, Mar del Plata, Argentina
}

This paper originates from a narrative inquiry into English teachers' identity carried out with 24 undergraduates at an Argentinean university English as an international language teacher education program. Grounded in a narrative conceptualization of identity, this enquiry gathered participants' storied field texts that were analyzed narratively. This paper explores how students' narratives disclosed the exercise of their agency concerning the program's curriculum by deciding how and when (not) to invest, reinvest, or divest their personal time in scheduled courses. We problematize these categories originating in undergraduates' narratives, connecting them to literature in the field of curriculum. The conclusion suggests the implications these situated findings entail for English as an international language teacher education curriculum and research.

Key words: English as an international language, teacher education, narrative inquiry, teacher identity, temporal investments, university curriculum.

Este trabajo se origina en una indagación narrativa sobre la identidad profesional docente de veinticuatro estudiantes de grado del profesorado de inglés en una universidad argentina. Anclada en

* $\quad$ Received: October 30, 2016. Accepted: December 15, 2016.

How to cite this article (APA 6th ed.):

Sarasa, M. C. (2017). A narrative inquiry into pre-service English teachers' temporal investments in their initial education curriculum. HOW, 24(1), 27-43. http://dx.doi.org/10.19183/how.24.1.337.

This article is licensed under a Creative Commons Attribution-NonCommercial-NoDerivatives 4.0 International License. License Deed can be consulted at http://creativecommons.org/licenses/by-nc-nd/4.0/. 
una conceptualización narrativa de la identidad, esta indagación recogió textos de campo de los participantes, analizándolos narrativamente. Exploramos el ejercicio de agenciamiento frente al currículo revelado por las narrativas. Éste implica (no) invertir, reinvertir o desinvertir el tiempo personal en las asignaturas. Problematizamos estas categorías originadas en las narrativas estudiantiles vinculándolas con la literatura en el campo del currículo. Las conclusiones sugieren las implicancias de estos hallazgos para el currículo de, y la investigación sobre, la formación inicial del profesorado de inglés.

Palabras clave: currículo universitario, formación del profesorado de inglés, identidad docente, indagación narrativa, inversiones temporales.

\section{Introduction}

The endeavors of teaching and learning English as an international language (EIL) in Portuguese- and Spanish-speaking South America are very interesting domains for exploring processes of in-service teacher identity construction (Renart \& Banegas, 2013). The current paper originates from a larger narrative inquiry whose overall aim was to elucidate identity construction processes of prospective English teachers studying in an Argentinean state university. Its main question centered on the query: How do undergraduates narrate their negotiation of their unfolding teacher identities? Our qualitative research employed the methodology and field-text gathering techniques of narrative inquiry (Connelly \& Clandinin, 2006). Participants were 24 sophomores enrolled in the above-mentioned university who participated in a research process spanning 18 months. Their identity narratives (mostly inclass gathered) were then re-written by the author with their collaboration and validation. This work focuses on narratives that revealed the exercise of undergraduates' agency (Norton \& Toohey, 2011) vis-à-vis their teacher education program's specified curriculum. These students determined how and when to invest, reinvest, or divest their individual time (Norton \& McKinney, 2011) in the courses they must take in order to graduate. The temporal negotiations vis-à-vis the curriculum retrieved from participants' stories allowed us to eventually address their real trajectories (Terigi, 2009, 2010) within the local domain of initial EIL teacher education.

\section{Literature Review}

The field of English language teaching (ELT) first concentrated on teacher and learner identity in 1997 when TESOL Quarterly's pivotal volume was published. Its editor characterized identity as referring to "how people understand their relationship to the world, how that relationship is constructed across time and space, and how people understand their possibilities for the future" (Norton, 1997, p. 410). EIL (prospective) teachers' and learners' identities are key to understanding their education, development, and practices in the sense that every time they "speak, read, or write" the English language, they are not 
merely "exchanging information" but "also organizing and reorganizing a sense of who they are and how they relate to the social world." As such, they are engaged in "identity construction and negotiation" (Norton, 2013, p. 4).

In the specific field of EIL teacher education (Johnson \& Golombek, 2002, 2011) there has been a growing concern about the need to study identity construction processes from the earliest stages of initial teacher preparation programs, which involve complex and situated trajectories. These studies would allow professionals and researchers to become fully attuned to the long-acclaimed sociocultural turn in ELT by focusing on praxis; legitimizing teachers' identity and practical knowledge; retracing the physical and digital boundaries of teacher education and development; as well as living, teaching, teaching to learn, and teaching to teach in "glocal" milieus (Johnson, 2006).

The above conceptualizations in the field of ELT have come together with narrative inquiry's research into general pre- and in-service teacher education. Narrative inquirers have defined teacher identity in terms of "narrative life compositions" (Clandinin, Cave, \& Cave, 2011, p. 1), which are expressed as "stories to live by" (Clandinin, Downey, \& Huber, 2009, p. 141). In brief, a narrative view of teacher identity holds the idea that

thinking of life as a story is a powerful way to imagine who we are, where we have been, and where we are going. In this view people live lives and tell stories of those lives, and people are characters in their own and others' life stories...We live stories. When we talk to others about ourselves we tell life stories. (Connelly \& Clandinin, 1994, pp. 149-150)

This definition allows us to envision teacher education and development as sites for inquiry where teachers and students live, tell, relive, and retell their experiences of who they have become, who they are becoming, and who they will become as they build their trajectories (Clandinin, Steeves, \& Chung, 2008). Their narrative identity

is indeed that story the person tries to "keep going"- an internalized and evolving narrative of the self that incorporates the reconstructed past and the imagined future into a more or less coherent whole in order to provide the person's life with some degree of unity, purpose, and meaning. (McAdams \& Pals, 2006, pp. 209-210)

In turn, this narrative definition of identity involves agency alongside its construction paths, since structures and contexts are not its only determinants. In our milieu, we conceive of agency as (future) teachers' fully autonomous capacity to act, to feel, and to adapt as well as to their ability to refuse and to resist (McAdams \& Pals, 2006). Agency is no simple movement but the human capability to engage in thoughtful action in order to become (Ricoeur, 2004). In this sense, (prospective) teachers' narratives reveal them as agents who, for example, struggle to study, to attain their graduation aims, or to avoid curricular hurdles. Agents realize their aims by co-authoring (with all those surrounding them) a script which 
they redraft for each specific setting where they interact (McAdams, Hanek, \& Dadabo, 2013), reframing "their relationship with others" as well as claiming "alternative, more powerful identities from which to speak, read or write" (Norton, 2013, p. 3).

Also closely associated with the notion of teacher identity construction and agency deployment is "the sociological construct of investment" (Norton, 2013, p. 3). Exploring pre-service teachers' investments in - the pledging of their resources to-learning and practicing the language within their education curriculum means paying careful attention to their degree of mobilization of the personal assets that they "spend" on their language acquisition and teacher education processes (Norton, 2000). Thus, the investments student-teachers make in their studies can involve different degrees of commitment of their personal (material, temporal, or attitudinal) resources. Contrariwise, they may decide to divest- to disengage-these resources away from the curriculum and into other domains. Lastly, various degrees of investment and divestment into the academic or the personal can, at any given time, be reinvested - redeployed — into either field at the expense of the other (Early \& Norton, 2012; Norton \& Early, 2011).

Finally, we need to situate the analytical categories of teacher identity, agency, and investment within the field of curriculum. We understand curriculum both as a site and as a proposal where different agents who hold diverse and often contradictory interests either struggle for mastery or resist domination. As the structure and character of curriculum "become" in the course of time, so do the identities of those who fight to negotiate-with varied degrees of success - their own curricular meanings within its arena (De Alba, 1998). In this light, the ways in which future teachers narrate their negotiations of different forms of temporal investments in their education curriculum are directly related to their agentive construction within their processes of identity formation.

\section{Methodology}

Our research is rooted in the qualitative paradigm (Denzin \& Lincoln, 2005), while the methodology adopted is that of narrative inquiry (Connelly \& Clandinin, 1990). From an ontological and an epistemological stance, narrative inquiry entails the study of experience as a storied phenomenon (Connelly \& Clandinin, 2006).

This paper stems from a larger narrative inquiry into the development of preservice EIL teachers' identity. Its context involved 24 sophomores attending an advanced English language communication course in an English teacher education program at an Argentinean state university. Most participants' oral and written narratives were gathered in the second quarter of 2014, during class sessions taught exclusively in English and led by the course's assistant professor, who was accompanied by two teaching assistants. During 2015, the author re-wrote 24 individual narratives for each participant-co- 
composing and validating them one by one with each student. In this way, the stories gathered in class were articulated within a single identity narrative text involving the 24 students' personal contributions. Subsequently, encounters were also held with all participants to further validate emerging categories (Creswell, 2007, 2012). Since the author is a senior teacher educator within the local program, she requested and obtained students' informed consent. Additionally, she deliberately maintained ethical safeguards (Clandinin \& Murphy, 2009). These involved rendering the narrative inquiry procedures as transparent as possible while avoiding excessive power asymmetries or the infliction of undue discomfort on students. Participants selected a pseudonym by which they wished to be identified in the research.

Instruments (re)designed for collecting oral and written field texts (Clandinin \& Caine, 2013) inside and outside the classroom were based on life-story interview topics and techniques (McAdams, 2008). We gathered seven oral and written narrative texts about the following:

1. The stories we read, watch, and listen to (Britzman, 1996).

2. Our educational biographies: primary, secondary, and university (Porta \& Sarasa, 2008).

3. Our linguistic biographies (Zacharias, 2011).

4. The greatest teachers we have ever had (Sarasa, 2008).

5. Our identity: Essay in the form of a textual intervention (Patterson, 2006; Pope, 1995).

6. Our own real-life heroes (De Laurentis, Porta, \& Sarasa, 2013).

7. The greatest challenges we have overcome (McAdams et al., 2013).

In addition, we collected four oral narratives involving the following:

1. Memory box: Describing an object that represents a turning point in our lives (Clandinin et al., 2008).

2. Roleplay: Experts' panel on EIL teaching and learning today (Vallack \& Charleson, 2007).

3. Class discussion: The wisest academic decision we have made at university (Roulston, 2008).

4. Personal conversations to validate emerging categories (McAdams, 2008). 
Subsequently, as stated, each student and the author co-composed 24 personal identity narratives consisting initially of the latter's chronological and thematic reconfiguration (Ricoeur, 2004) of the above mentioned oral and written narrative texts. This co-authoring of stories and their reconfiguration encompasses the researcher's narrative conceptualization (Creswell, 2007, 2012). In other words, according to the tenets of narrative inquiry—our research methodology—retelling involves narrative as an ontology - a narrative way of being — and as an epistemology - a narrative way of knowing about, in this case, identity, agency, and curriculum (Bruner, 1991; Clandinin \& Murphy, 2009). In this sense, "narrating can be considered an interactive process of jointly constructing and interpreting experience with others; therefore narrative analysis is potentially a means of examining participant roles in constructing accounts and in negotiating perspectives and meanings" (Cortazzi, 2001, p. 384). Concepts that emerged naturally from these stories co-composed with the students were validated during online exchanges via e-mail or the course's virtual learning environment (VLE) on Edmodo and also during the personal meetings held throughout 2015 (Constantino, 2008). To explain how we interwove our narrative analysis, the elaboration of categories arising from the co-composed narratives, and their interplay with the literature in the discussion, we refer to a process of crystallization in the sense that

the central imaginary for "validity" is not the triangle_ — a rigid, fixed, two dimensional object. Rather, the central imaginary is the crystal, which combines symmetry and substance with an infinite variety of shapes, substances, transmutations, multi-dimensionalities, and angles of approach... What we see depends on our angle of repose- not triangulation but rather crystallization. (Richardson \& St. Pierre, 2005, p. 963)

To conclude, our narrative analysis of participants' texts is, on the one hand, thematic since it involved first retelling and then conceptualizing the subject matter and chronology of their stories. On the other hand, it is dialogic, based on a co-construction process-that also involved validation in the form of crystallization-between the participants and the researcher (Riessman, 1993).

\section{Results}

In this section, we conceptualize narratively participants' different forms of investing, divesting, and reinvesting their time in their prescribed curriculum, highlighting their voices in their own authorial quotes. 


\section{Temporal Investments in the Curriculum}

Only four students devoted most of their time to studying. Among them, Savannah was the only participant who followed the temporal ordering of the mandated curriculum, some adaptations notwithstanding. She told us that

In August [2014] I sat for my first final exam ever and failed it but surprisingly when I got home I didn't cry. . . . That helped me realize that failing an exam was not the end of the world. . . . Everything ... was still the same. . . As I see myself differently, I was able to miss a week here and go on holidays with my family. [Up until then] missing a whole week of classes would have been the end of the world but this year I did it. . . I'm still here.

In addition, Savannah chose to

give quite a lot of importance to my study time... My mum and dad support me not only personally but also economically. . . . I've been a very exacting person all my life, always devoted to my studies . . . because they provide me with satisfactions in spite of the sacrifices they demand.

For her part, her friend Sofía achieved some degree of equilibrium, confessing that "it is really very demanding to take four courses each quarter, but I think I have succeeded in managing the time I devote to my activities and that I devote to school."

In turn, although Coty did not take four courses each quarter, she allocated a great deal of her time to her studies. She disregarded her personal life, admitting that "I study all day." She and her friend Jo also bet some strategic temporal stakes on their academic trajectories. In their freshman year, when they examined the sequencing and consecutive courses of the curriculum, they decided to attend only two courses instead of the mandated three during two successive quarters. Thus, they did not feel trapped at the beginning of any quarter by having no consecutive subjects available for them to take. In this way, they explained that they were able to study more and consequently obtain better grades. Finally, Grian harmonized all her activities since her academic life was one of her pleasures. She explained that "my personal time and my study time mingle all the time because I basically live at school."

\section{Temporal Investments In-Between the Curriculum and the Personal Domain}

Another four students were unable to make up their minds as to whether to spend curricular or personal time. For example, Marilyn wavered between two extremes. The first involved attending fewer courses per quarter because "when I took four subjects I was overwhelmed and had no social life." However, feeling "really bad" about lengthening her course of study, she posed a number of questions: 
What shall I do? Shall I be happy during my youth? . . Shall I go out with friends, see my family . . . have a social life, and prolong my studies? ... Shall I study once and for all and then enjoy life?

Likewise, Ant experienced pressures in the sense that "when I'm studying I devote little time to my personal life. ... I feel guilty if I go dancing with friends and I can't study. Even if I stay at home doing nothing ... I feel guilty." Along the same lines, Polka Dots, who had been in the teacher education program for over ten years, admitted that

the importance I assign to my personal time has clearly influenced my decisions. . . . Frustrations over having to drop out of courses; rage over failing a course to which I hadn't devoted enough time; rushing; sleepless nights before midterms; the constant feeling that I'm not getting anything right.

Lastly, Tute's case was similar to Polka Dots's. He had been at university for over ten years since "I didn't have enough time, or may be energy, to study and, at some point, this must have made me fail and thus I had to take courses again." He considered that "personal time is critical" in order to "learn a heap of things that can be applied in class." This slowing down of the pace of his studies was partly due to restricted schedule options that prevented him from reconciling his work timetable with that of overlapping subjects at different levels of the curriculum.

\section{Temporal Reinvestments in the Curriculum}

This group includes six sophomores. They all reinvested their time in the program when they became focused on their graduation. After studying for six years, Clara reinvested her time in studying, feeling that she "could do it" when she stopped thinking she "was not intelligent enough to be studying English at university." For her part, Fátima had to opt between working many hours at a shop and continuing her studies. She admitted that "I chose to go on studying" although she devoted "too much time to studying" even if she never took four courses per quarter. Next, Emma revealed that she had to discontinue the intensive practice of Taekwondo and hockey "for a while" since "I had to attend a lot of courses over again because I couldn't focus on what I'm doing here" and because "I like the program." After her new temporal reinvestment she noticed she was performing much better. Similarly, Maggie indicated that at a given point she was forced to attend fewer courses in order to look after a sick parent. However, she acknowledged her reinvestment after six years in the program in the sense that "when I entered university I definitely cared about my personal time. . . For a little over a year now I think that study time is my priority." Then, Juana graduated from high school over seven years ago. In this, her third university course of study, she explained that "I am aware of the fact that if I want to graduate . . . if I don't study I won't succeed. So I study most of the time." Finally, Rusa gave up her personal time when she started working as a teacher: "that's it. . . I've reached 
adulthood. .. . I hadn't noticed and now it's happened." She wanted to graduate but in her own time, remembering her father's advice never to feel rushed. For her, this means that "I'll graduate when I graduate. Luckily, we can work as teachers and acquire experience. . . . People in other programs can't."

\section{Temporal Divestment in the Curriculum and Reinvestment in the Personal Domain}

Unlike the previous cases, only one student divested her study time to reinvest it in her work and her personal life. Shelia Tarnosky said that “it doesn't matter whether we spend many hours studying, may be we'll achieve the same results. . . . Now I chill out and I can tell you that I'm not doing that badly." She agreed with other participants about the weak link existing between, on the one hand, academic success and, on the other, temporal investment in some curricular subjects. She often wondered "if it's worth neglecting my personal stuff and spending ten thousand hours studying for a subject because I'm not sure studying hard will actually make me succeed."

\section{Temporal Investments in the Personal Domain}

The last group of participants includes nine undergraduates who valued their personal time above all else. Jo was aware of the fact that "I always did well at school and at university but I've never . . . devoted all my time to that." Rose, Married, Victoria, and Cas focused mostly on their personal time. In this way, after her freshman year, Rose became determined to never again take four subjects per quarter because "I'm not going to be stressed out like that; ... I'm going to focus on having a life outside college." Similarly, Lily made up her mind to "never . . let college keep me from doing what I want to do." For his part, Married decided to marry his long-standing girlfriend before they both graduated from the program. At present, he juggles the responsibilities of home, work, and college while trying to strike "a balance." Likewise, Cas struck another "balance," indicating that "personal time is important. Even if we have to think about the future we mustn't forget the now." Next, Victoria admitted that "prioritizing my private time means the course of study is taking me much longer than I expected." In turn, Haven underwent a severe crisis when she failed two out of her four freshman courses during her first quarter, until she realized "I wasn't me; I just wasn't ready for so many subjects." Then, Unnamed revealed that time allowed him "to realize that I have other instances and that I would eventually pass those ... finals in spite of the many knock-out punches I received in this course of study." Finally, James conceded the fact that he enjoyed his private time at the expense of slowing down his academic trajectory. 


\section{Discussion}

If we revisit our overarching research question in terms of how these undergraduates retell their negotiation of their unfolding teacher identities (Clandinin et al., 2011; Clandinin et al., 2009; Connelly \& Clandinin, 1994; Norton, 1997) vis-à-vis the prescribed curriculum, we can see that these future English teachers displayed their agency (McAdams \& Pals, 2006; McAdams et al., 2013; Norton, 2013; Ricoeur, 2004) since they decided when to graduate. In other words, they determined when to become fully-fledged English teachers, that is, when to acquire the identity of an English teacher. Their narratives revealed the fact that they considered time as a highly valuable asset which they invested in becoming graduate teachers according to the different possibilities they envisioned (Norton \& McKinney, 2011). In this sense, student-managed time was not always devoted to following the chronological sequencing of the prescribed curriculum that allows undergraduates to "turn into" English teachers (Gimeno Sacristán, 1998). The narratives we gathered disclosed only four (Savannah, Sofía, Coty, and Grian) constant temporal investments that would lead to the fast completion of the university program and acquisition of a complete teacher identity. Four other stories (Marilyn, Ant, Polka Dots, and Tute) expressed several difficulties resolving tensions between academic and private concerns. Their tellers remained "in between" as regards being students and future teachers. There were six reinvestments (Clara, Fátima, Emma, Maggie, Juana, and Rusa) in curricular time after protracted itineraries in the course of study. These students had adopted a new, faster pace towards becoming teachers. However, there was one case (Sheila Tarnosky) of temporal divestment in the curriculum in favor of personal reinvestment which meant the undergraduate stayed on as a student. The remaining nine participants (Jo, Rose, Married, Victoria, Cas, Lily, Haven, Unnamed, and James) seemed to favor the personal domain at the expense of the academic one. They were firmly anchored in a full student identity, away from that of a teacher.

Next, when we re-inscribe our narrative analysis in the field of curriculum as a site where different agents struggle to make their interests prevail or to repel dominance (De Alba, 1998), we can see this English teacher education program as a place where our students vied in the negotiation of those meanings they created (Dewey, 1916/1930; McAdams, 2013a, 2013b). Challenging a uniform, impersonal course of study, these participants achieved mastery of their temporal investments. In this sense, we could refer to two loci of control, that is, an internal and an external one (Camilloni, 2013). The internal locus is in turn divided into two parts. On the one hand, our students' exercised control over their choices about not attending courses; attending them (again), dropping out, limiting the number of courses taken, or devoting more or less time to studying. When Maggie told us that "when I entered university I definitely cared about my personal time. . . . For a little over a year now I think that study time is my priority," she seemed to be exercising her different control options in the reinvestment of her time. On the other hand, our undergraduates exercised self-control; 
for instance, their capacity to curb their emotions before repeated failures or external criticisms. Savannah's disclosure revealed that "in August [2014] I sat for my first final exam ever and failed it but surprisingly when I got home I didn't cry. . . . That helped me realize that failing an exam was not the end of the world." Both facets of this internal locus of control were articulated by those stories we retrieved unveiling strategies for coping with subjectively perceived curricular demands and academic work overload (Kyndt, Berghmans, Dochy, \& Bulckens, 2014). Juana indicated that "if I want to graduate . . if I don't study I won't succeed. So I study most of the time." Then, by means of their external locus of control, these students realized that what happened to them depended on random exam and class situations, or other institutional factors where objective curricular time operated separately from agency. Sheila Tarnosky hinted at her bewilderment concerning whether "it's worth neglecting my personal stuff and spending ten thousand hours studying for a subject because I'm not sure studying hard will actually make me succeed."

The nature of the prescribed curriculum for the actual English teacher education program these participants were following is characterized by its objective rigidity. Its sequencing is tightly organized along four years with inflexible consecutives and no electives. However, our qualitative research suggests that this lack of elasticity with its stringent formal controls appeared to be subjected to the amount of time each of our 24 students decided to devote to the course of study during an academic trajectory that seemed individually rather than uniformly organized (Camilloni, 2001). These particular students chose how to steer their academic paths by regulating how much time they allotted to studying and taking courses. Thus, Coty and Jo designed their own plan for attending the number of courses they had decided to take during two running quarters at the beginning of their course of study. In this sense, although the curriculum we are describing is inflexible (Gimeno Sacristán, 1998), we read about the ways in which some of the participants found loopholes through which they traced their own curricular routes and, again, set the limits to the number of courses they attended per quarter. This happened when Rose made up her mind to never again take four quarterly subjects after her failed experience during her freshman year. Some of our participants seemed to have negotiated a way out of the prescribed curricular time dominating their lives (Schön, 1992) by looking for, and finding, alternatives that have been categorized as relief points along their course of study (Maggio, 2013). In addition to decisions involving taking fewer subjects, these respites were also obtained by longer dedication to the personal domain, by working outside of college, or simply by relaxing. For that reason, Tute considered that "personal time is critical" in order to "learn a heap of things that can be applied in class." Rusa started working, Married got married, and Sheila chilled out. These stories suggest that these future English teachers whose narratives we gathered did not regard the mandated curriculum as a one-way course of study but as their very own unfolding life project. 
This faith placed by the 24 students in their internal locus of control over their time investments, reinvestments, and divestments allowed us to visualize their agency as their individual capacity to obtain desired results. The narratives we co-composed expressed a sense of achievement about obtaining curricular relief (Maggio, 2013). It was expressed in Married's and Cas's words about the "balance" they attained concerning time devoted to, on the one hand, studying and, on the other, to leisure, family, or friends. Moreover, agency (Norton \& Toohey, 2011) enabled their reflexive action (Dewey, 1916/1930) over university trajectories, overcoming hurdles that slowed down or stalled these transits. This happened when Clara reinvested her time in studying, feeling she "could do it" as she stopped believing that she "was not intelligent enough to be studying English at university." In our inquiry, agency also displayed resilience (Day et al., 2006), the positive capacity to surmount different hurdles, that is, overcoming academic failures, delays, or interruptions. Thus, Unnamed told us that time enabled him "to realize that I have other instances and that I would eventually pass those ... finals in spite of the many knock-out punches I received in this course of study." For our undergraduates, this positive ability also meant facing up to excessive demands: Marilyn decided to, once more, attend fewer courses per quarter since "when I took four subjects I was overwhelmed and had no social life." Finally, resilience also concerned blending private and curricular obligations as in Grian's case when she claimed that "my personal time and my study time mingle all the time because I basically live at school."

These agentic narratives we retrieved in our situated narrative inquiry evinced traces of the heroic, fighting spirit revealed in narratives of local memorable university professors' biographies characterizing the struggles they faced during their academic lives in terms of an odyssey (Álvarez, Porta, \& Sarasa, 2010). In a similar vein, we read about Lily's decision to "never ... let college keep me from doing what I want to do." Within our specific inquiry context, these students' narratives suggested that their lived temporalities did not fully succumb before the rules of the mandated curriculum.

\section{Conclusion}

Our findings, as well as our attempts to answer the research question posed, reveal our students' exercise of their agency in the personal, temporal investments, reinvestments, and divestments (Norton, 1997, 2013) they make concerning the sequencing of their mandated ELT course of study and the acquisition of a graduate English teacher identity. In this sense, one of the contributions of our inquiry lies in the fact that it has enabled us to look at how these future teachers retold their actual, lived, curricular trajectories (Terigi, 2009, 2010) rather than at how these routes are documented in the theoretical, standardized forms prescribed in their EIL teacher education program. Our study disclosed complex undergraduates' agentic strategies to control curricular time and determine study paths that will lead them to become 
English teachers. In turn, this process is linked to research concerned with internal and internal loci of control found within the field of curriculum (Camilloni, 2013; Kyndt et al., 2014; Maggio, 2013; Schön, 1992).

Our inquiry also helps us to understand the differential gap between curricular futureoriented time and the individual — circuitous, digressional, backwards or forward moving, and stationary — rhythms of student-lived time (Ricoeur, 2004) as told in the personal stories we gathered (Davini, 2015). In a paper titled "Identity and a model of investment in applied linguistics", Darvin and Norton argue that all EIL students need to be reassured about the fact that their investments in the learning process count as "an affirmation of their identity, a legitimation of their rightful place" (2015, p. 10). In our case, this happened within the teacher education program where students have agentially engaged in the lengthy process of becoming teachers.

Although our research has been limited in time and scope-concentrating intensely on a small number of participants rather than longitudinally on a much larger group —and is likewise confined to its very narrative epistemology, it is still relevant to the profession and to future research. Our narrative conceptualizations of different forms and degrees of future English teachers' investments in the acquisition of a graduate teacher identity as powerfully tied to the exercise of their agency strongly suggest that EIL initial teacher education should probe more deeply into the construction of students' real academic paths and their bearing on teacher identity. In this sense, narrative inquiries should not only gather more varied narratives and counter-narratives from longitudinal cohorts of future teachers and from their teacher educators but also incorporate forms of narrative knowledge into the very contents of the curriculum for initial teacher education.

The overall implications of our research point to the significance of carrying out narrative inquiry into EIL teacher identity construction within the initial education curriculum. This is especially relevant to us in Spanish-speaking South America, where EIL (prospective) teachers' identities have remained mostly under-represented in the specialized literature (Barahona, 2016) despite the continent's vast expanse and its long standing EIL teacher education programs. To this end, the current paper has attempted to bring to the fore some, so far unheard, future teachers' voices from the Southern Cone (Nieto Cruz \& Cárdenas, 2015) narrating their curricular paths and investments towards becoming graduate English teachers.

\section{References}

Álvarez, Z., Porta, L., \& Sarasa, M. C. (2010). Una exploración del rol de los mentores en las trayectorias profesionales de los buenos docentes universitarios. Praxis Educativa, 14(14), 42-48. 
Barahona, M. (2016). English language teacher education in Chile: A cultural historical activity theory. New York, US: Routledge.

Britzman, D. P. (1996). Pedagogy and transference: Casting the past of learning into the presence of teaching. Theory into practice, 35(2), 117-123. https://doi.org/10.1080/ 00405849609543711.

Bruner, J. (1991). The narrative construction of reality. Critical inquiry, 18(1), 1-21. https://doi. org/10.1086/448619.

Camilloni, A. (2001). Modalidades y proyectos de cambio curricular. In A. Pulpeiro, N. Schuster, \& J. Milei (Chair), Aportes para el cambio curricular en Argentina 2001 (pp. 23-52). Buenos Aires, AR: Universidad de Buenos Aires.

Camilloni, A. (2013). La inclusión de la educación experiencial en el currículo universitario. In G. Menéndez (Ed.), Integración docencia y extensión: otra forma de enseñary de aprender (pp. 11-21). Santa Fe, AR: Universidad Nacional del Litoral.

Clandinin, D. J., \& Caine, V. (2013). Narrative inquiry. In A. A. Trainor \& E. Graue (Eds.), Reviewing qualitative research in the social sciences (pp. 166-179). New York, US: Routledge.

Clandinin, D. J., Cave, M. T., \& Cave, A. (2011). Narrative reflective practice in medical education for residents: composing shifting identities. Advances in Medical Education and Practice, 2, 1-7.

Clandinin, D. J., Downey, C. A., \& Huber, J. (2009). Attending to changing landscapes: Shaping the interwoven identities of teachers and teacher educators. Asia-Pacific Journal of Teacher Education, 37(2), 141-154. https://doi.org/10.1080/13598660902806316.

Clandinin, D. J., \& Murphy, M. S. (2009). Comments on Coulter and Smith: Relational ontological commitments in narrative research. Educational Researcher, 38(8), 598-602. https://doi. org/10.3102/0013189X09353940.

Clandinin, D. J., Steeves, P., \& Chung, S. (2008). Creando espacios de investigación narrativa en la formación del profesorado. In L. Porta \& M. C. Sarasa (Eds.), Formación y desarrollo de la profesión docente en el profesorado: las buenas prácticas y sus narrativas (pp. 59-83). Mar del Plata, AR: Universidad Nacional de Mar del Plata.

Connelly, F. M., \& Clandinin, D. J. (1990). Stories of experience and narrative inquiry. Educational Researcher, 19(5), 2-14. https://doi.org/10.3102/0013189X019005002.

Connelly, F. M., \& Clandinin, D. J. (1994). Telling teaching stories. Teacher Education Quarterly, 21(1), $145-158$.

Connelly, F. M., \& Clandinin, D. J. (2006). Narrative inquiry. In J. L. Green, G. Camilli, \& P. B. Elmore (Eds.), Handbook of complementary methods in education research (pp. 477-487). Mahwah, US: Lawrence Erlbaum.

Constantino, T. E. (2008). Constructivism. In L. M. Given (Ed.), The SAGE encyclopaedia of qualitative research methods (Vols. 1 \& 2, pp. 116-119). Los Angeles, US: SAGE.

Cortazzi, M. (2001). Narrative analysis in ethnography. In P. Atkinson, A. Coffey, S. Delamont, J. Lofland, \& L. Lofland (Eds.), Handbook of ethnography (pp. 384-395). London, UK: SAGE. https://doi.org/10.4135/9781848608337.n26. 
Creswell, J. W. (2007). Qualitative inquiry \& research design: Choosing among five approaches. Thousand Oaks, US: SAGE.

Creswell, J. W. (2012). Educational research: Planning, conducting and evaluating quantitative and qualitative research. Boston, US: Pearson.

Darvin, R., \& Norton, B. (2015). Identity and a model of investment in applied linguistics. Annual Review of Applied Linguistics, 35, 36-56. https://doi.org/10.1017/S0267190514000191.

Davini, M. C. (2015). La formación en la práctica docente. Buenos Aires, AR: Paidós.

Day, C., Stobart, G., Sammons, P., Kington, A., Gu, Q., Smees, R., \& Mujtaba, T. (2006). Variations in teachers' work, lives and effectiveness (Research Report No. 743). London, UK: Department for Education and Skills.

De Alba, A. (1998). Curriculum: crisis, mito y perspectivas. Buenos Aires, AR: Miño \& Dávila.

De Laurentis, C., Porta, L., \& Sarasa, M. C. (2013). La formación del profesorado de inglés: espacios de indagación narrativa. Arena, 3(1), 1-22.

Denzin, N. K., \& Lincoln, Y. S. (Eds.). (2005). The SAGE handbook of qualitative research. Thousand Oaks, US: SAGE.

Dewey, J. (1916/1930). Democracy and education: An introduction to the philosophy of education. New York, US: The MacMillan Company.

Early, M., \& Norton, B. (2012). Language learner stories and imagined identities. Narrative Inquiry, 22(1), 194-201. https://doi.org/10.1075/ ni.22.1.15ear.

Gimeno Sacristán, J. (1998). El currículum: una reflexión sobre la práctica. Madrid, ES: Morata.

Johnson, K. E. (2006). The sociocultural turn and its challenges for second language teacher education. TESOL Quarterly, 40(1), 235-257. https://doi.org/10.2307/40264518.

Johnson, K. E., \& Golombek, P. R. (2002). Inquiry into experience: Teachers' personal and professional growth. In K. E. Johnson \& P. R. Golombek (Eds.), Teachers' narrative inquiry as professional development (pp. 1-14). Cambridge, UK: Cambridge University Press.

Johnson, K. E., \& Golombek, P. R. (2011). The transformative power of narrative in second language teacher education. TESOL Quarterly, 45(3), 486-509.

Kyndt, E., Berghmans, I., Dochy, F., \& Bulckens, L. (2014). 'Time is not enough.' Workload in higher education: A student perspective. Higher Education Research \& Development, 33(4), 684698. https://doi.org/10.1080/07294360.2013.863839.

Maggio, M. (2013, April 22). Qué temas o problemas deberían formar parte de la agenda de TIC y Educación en Iberoamérica. Presented at the Jornadas sobre TIC y educación, Buenos Aires, Argentina. Retrieved from http://www.ibertic.org/temasagenda2.php.

McAdams, D. P. (2008). The life story interview. Evanston, US: Northwestern University.

McAdams, D. P. (2013a). Life authorship: A psychological challenge for emerging adulthood, as illustrated in two notable case studies. Emerging Adulthood, 1(2), 151-158. https://doi. org/10.1177/2167696813481774. 
McAdams, D. P. (2013b). The psychological self as actor, agent, and author. Perspectives on Psychological Science, 8(3), 272-295. https://doi.org/10.1177/1745691612464657.

McAdams, D. P., Hanek, K. J., \& Dadabo, J. G. (2013). Themes of self-regulation and self-exploration in the life stories of religious American conservatives and liberals. Political Psychology, 34(2), 201-219. https://doi.org/10.1111/j.1467-9221.2012.00933.x.

McAdams, D. P., \& Pals, J. L. (2006). A new Big Five: Fundamental principles for an integrative science of personality. American Psychologist, 61(3), 204-217. https://doi.org/10.1037/0003066X.61.3.204.

Nieto Cruz, M. C., \& Cárdenas, M. L. (2015). Editorial. PROFILE Issues in Teachers' Professional Development, 17(1), 7-9. https://doi.org/10.15446/profile.v17n1.48168.

Norton, B. (1997). Language, identity, and the ownership of English. TESOL Quarterly, 31(3), 409429. https://doi.org/10.2307/3587831.

Norton, B. (2000). Identity and language learning: Gender, ethnicity and educational change. Harlow, UK: Pearson.

Norton, B. (2013). Identity and language learning: Extending the conversation (2nd ed.). Bristol, UK: Multilingual Matters.

Norton, B., \& Early, M. (2011). Researcher identity, narrative inquiry, and language teaching research. TESOL Quarterly, 45(3), 415-439.

Norton, B., \& McKinney, C. (2011). An identity approach to second language acquisition. In D. Atkinson (Ed.), Alternative approaches to second language acquisition (pp. 73-94). London, UK: Routledge.

Norton, B., \& Toohey, K. (2011). Identity, language learning, and social change. Language Teaching, 44(04), 412-446. https://doi.org/10.1017/S0261444811000309.

Patterson, G. (2006). I am one of the people. In G. Patterson (Ed.), Lapsed Protestant (pp. 9-11). Dublin, IE: New Island.

Pope, R. (1995). Textual intervention. London, UK: Routledge.

Porta, L., \& Sarasa, M. C. (Eds.). (2008). Formación y desarrollo de la profesión docente en el profesorado: las buenas prácticas y sus narrativas. Mar del Plata, AR: Universidad Nacional de Mar del Plata.

Renart, L., \& Banegas, D. L. (Eds.). (2013). Roots \& routes in language education: Bi/ multi/plutilingualism, interculturality and identity (Selected papers from the 38th FAAPI Conference). Buenos Aires, AR: FAAPI-APIBA.

Richardson, L., \& St. Pierre, E. A. (2005). Writing: A method of inquiry. In N. K. Denzin \& Y. S. Lincoln (Eds.), The SAGE handbook of qualitative research (3rd ed., pp. 959-978). Thousand Oaks, US: SAGE.

Ricoeur, P. (2004). Tiempo y narración I: configuración del tiempo en el relato histórico. Buenos Aires, AR: Siglo XXI.

Riessman, C. K. (Ed.). (1993). Narrative analysis (Vol. 30). Thousand Oaks, US: SAGE. 
Roulston, K. J. (2008). Conversational interviewing. In L. M. Given (Ed.), The SAGE encyclopaedia of qualitative research methods (Vols. 1 \& 2, pp. 128-130). Los Angeles, US: SAGE.

Sarasa, M. C. (2008). En torno a los modelos de la buena enseñanza. In L. Porta \& M. C. Sarasa (Eds.), Formación y desarrollo de la profesión docente en el profesorado: las buenas prácticas y sus narrativas (pp. 183-217). Mar del Plata, AR: Universidad Nacional de Mar del Plata.

Schön, D. A. (1992). La formación de profesionales reflexivos: hacia un nuevo diseño de la enseñanza y el aprendiraje en las profesiones. Barcelona, ES: Paidós.

Terigi, F. (2009). Las trayectorias escolares: del problema individual al desafío de la politica educativa. Buenos Aires, AR: Centro Nacional Información Documental Educativa.

Terigi, F. (2010). Las cronologías de aprendizaje: un concepto para pensar las trayectorias escolares. In Ministerio de Cultura y Educación (Ed.), Jornada de Apertura Ciclo Lectivo 2010 (pp. 1-29). Santa Rosa, AR: Gobierno de La Pampa.

Vallack, J. M., \& Charleson, I. (2007, January). E-role play for inquiry into transnational education. Proceedings of ASCILITE Singapore 2007 (pp. 1036-1040). Retrieved from http://www.ascilite. org/conferences/singapore $07 /$ procs/vallack-poster.pdf.

Zacharias, N. T. (2011). An English teacher struggle to establish voice in the periphery. k@ta, 13(1), 64-77. https://doi.org/10.9744/kata.13.1.64-77.

\section{The Author}

María Cristina Sarasa is a full time tenured EIL teacher educator in the Department of Modern Languages and a researcher with the Centro de Investigaciones Multidisciplinarias en Educación (CIMEd, CLACSO affiliated member center) in the School of Humanities, Universidad Nacional de Mar del Plata, Argentina. 